\title{
Effects of dietary sepiolite on performance, egg quality and some blood parameters in laying hens
}

\author{
Sakine YALÇIN ${ }^{1}$, Handan ESER ${ }^{2}$, İlyas ONBAŞILAR ${ }^{3}$, Suzan YALÇIN ${ }^{4}$, \\ Fatma KARAKAŞ OĞUZ ${ }^{5}$
}

\begin{abstract}
${ }^{1}$ Ankara University, Faculty of Veterinary Medicine, Department of Animal Nutrition, Ankara; ${ }^{2}$ Abant İzzet Baysal University, Faculty of Agriculture and Natural Sciences, Department of Poultry Farming, Bolu; ${ }^{3}$ Hacettepe University, Faculty of Medicine, Laboratory Animal Breeding and Research Unit, Ankara; ${ }^{4}$ Selçuk University, Faculty of Veterinary Medicine, Department of Food Hygiene and Technology, Konya; ${ }^{5}$ Mehmet Akif Ersoy University, Faculty of Veterinary Medicine, Department of Animal Nutrition, Burdur, Turkey.
\end{abstract}

Summary: The aim of this study was to determine the effects of dietary sepiolite on performance, egg quality, egg yolk cholesterol content and some blood parameters of laying hens during 22 weeks period. For this purpose a total of 135 Lohmann Brown laying hens, 38 weeks of age, were allocated to one control group and two treatment groups. Sepiolite was used at the level of $0,0.5$ and $1 \%$ for the diets of control group and the first and second treatment groups, respectively. Dietary sepiolite supplementation did not significantly affect feed intake, egg production, egg weight and feed conversion ratio. The values of egg breaking strength $(p<0.01)$ and egg shell thickness $(p<0.05)$ were increased, egg yolk cholesterol was decreased $(p<0.05)$ by the usage of $1 \%$ sepiolite in the diet. Dietary treatments did not significantly affect egg shape index, egg albumen height, egg albumen index, egg yolk index and egg Haugh unit. Dietary sepiolite at $1 \%$ reduced cholesterol and triglyceride in serum $(\mathrm{p}<0.05)$ and increased total protein in serum $(\mathrm{p}<0.01)$. It was concluded that dietary supplementation of $1 \%$ sepiolite was effective feed additive in layer feeding due to the reduction in egg yolk cholesterol and improvement in egg shell quality.

Key words: Blood parameters, egg quality, laying hen, performance, sepiolite.

\section{Yumurta tavuğu rasyonlarına sepiyolit ilavesinin performans, yumurta kalitesi ve bazı kan parametreleri üzerine etkisi}

Özet: Bu araştırma, yumurta tavuğu rasyonlarına sepiyolit ilavesinin 22 hafta süreyle performans, yumurta kalitesi ve bazı kan parametreleri üzerine etkilerini belirlemek amacıyla yapılmıştır. Bu amaçla 38 haftalık yaşta 135 adet Lohmann Brown yumurta tavuğu 1 kontrol ve 2 deneme grubuna ayrılmıştır. Sepiyolit kontrol, birinci ve ikinci deneme gruplarının rasyonlarında sırasıyla \% 0 , 0.5 ve 1 olacak şekilde ilave edilmiştir. Sepiyolit ilavesi yem tüketimi, yumurta verimi, yumurta ağırlı̆̆ ve yemden yararlanmayı etkilememiştir. Rasyonlarda \%1 düzeyinde sepiyolit kullanılmasıyla yumurta kırılma mukavemeti $(\mathrm{p}<0.01)$ ve yumurta kabuk kalınlığı $(p<0.05)$ artmış, yumurta kolesterol düzeyi $(p<0.05)$ azalmıştır. Rasyonda sepiyolit bulunması yumurta şekil indeksi, ak yüksekliği, ak indeksi, sarı indeksi ve Haugh birimini önemli derecede etkilememiştir. Sepiyolitin \%1 düzeyinde bulunması serum kolesterol ve trigliserit düzeylerini azaltmış $(\mathrm{p}<0.05)$, toplam protein düzeyini $(\mathrm{p}<0.01)$ artırmışır. Sonuç olarak rasyona \%1 düzeyinde sepiyolit ilavesi yumurta kolesterol düzeyini azaltması ve yumurta kabuk kalitesini iyileştirmesi bakımından yumurta tavuğu beslemede etkili bir yem katkı maddesi olacağı kanısına varılmıştır.

Anahtar sözcükler: Kan parametreleri, performans, sepiyolit, yumurta kalitesi, yumurta tavuğu.

\section{Introduction}

Sepiolite is a natural ingredient, clay family known as sepiolite-palygorskite. It is a hydrated magnesium silicate. It has high porosity and surface area, strong absorptive power, high structural stability and chemically inertia. Sepiolite inclusion in the diets reduces dust losses, improves pellet durability and quality, improves nutrient digestion and faeces consistency. According to the report of EFSA panel on additives and products or substances used in animal feed (FEEDAP), data from more than 20 studies in chickens for fattening, laying hens, pigs and rabbits indicate that sepiolite can be used upto $2 \%$ without adverse effects in these species (9).

Sepiolite may replace growth factors, antibiotics and anticoccidials in poultry diets $(3,12,18,24,26)$. Eser et al. (10) reported that $1 \%$ sepiolite in the diets increase body weight gain and reduce the relative weight of abdominal fat and the levels of serum cholesterol and triglyceride in broilers. Ayed et al. (3) concluded that 0.5, 1 and 2\% sepiolite supplementation improved growth 
and feed efficiency. The inclusion of $1.5 \%$ sepiolite in layer diets increased egg production and improved feed conversion ratio (15). Internal and external egg quality characteristics were not affected by $1.5 \%$ sepiolite supplementation (15). Mizrak et al. (14) reported that sepiolite usage at the level of 1 and $2 \%$ in the layer diets didn't affect egg production, egg weight, feed consumption, feed conversion ratio and egg quality characteristics. Sepiolite addition to the diets containing low calcium increased the hatchability (14). Tortuero et al. (25) also observed that sepiolite supplementation did not influence egg production, egg shell quality, calcium retention and blood calcium, phosphorus and magnesium levels. However the use of sepiolite for poultry nutrition is limited. The objective of this research was to determine the effects of sepiolite supplementation on performance, egg quality, egg yolk cholesterol content and some blood parameters in laying hens.

\section{Materials and Methods}

Material: A total of 135 Lohmann Brown laying hens aged 38 weeks were used in this study. Hens were randomly allocated into one control group and two treatment groups each containing 45 hens. Each group was divided into five replicates as subgroups, comprising nine hens each. They were housed in cages $(30 \mathrm{~cm} \times 44 \mathrm{~cm} \times 44 \mathrm{~cm})$ in a windowed poultry house with a $16 / 8 \mathrm{~h}$ light/dark regimen. Feed in mash form and water were provided ad libitum during the 22 week experimental period. The ingredients and chemical composition of the diets are shown in Table I. Sepiolite (Sivrihisar- Eskişehir, Turkey) was used at the level of 0, 0.5 and $1 \%$ for the diets of control group and the first and second treatment groups, respectively. This study was conducted by the researchers based on protocols by Ankara University Ethical Commission Report (No:2013/13/93).

Traits measured: Nutrient composition of the diets were determined according to the AOAC (2). The samples were ashed in a muffle furnace prior to the analysis of calcium (11) and total phosphorus (1). Metabolizable energy levels of samples were estimated using the equation of Carpenter and Clegg (6).

Hens were weighed individually at the beginning and at the end of the experiment. Mortality was recorded as it occurred. Eggs were collected daily and egg production was expressed on a hen day basis. All the eggs laid during the last two consecutive days of every week were collected and weighed individually to determine the egg weight. Feed intake was recorded biweekly and calculated as $\mathrm{g}$ feed per day per hen. The feed conversion ratio was calculated as $\mathrm{g}$ feed per $\mathrm{g}$ egg.
Table 1. Ingredients and chemical composition of the experimental diets.

Tablo 1. Deneme rasyonlarının içeriği ve kimyasal bileşimi.

\begin{tabular}{lccc}
\hline $\begin{array}{l}\text { Ingredients } \\
(\%)\end{array}$ & $\begin{array}{c}\text { Control } \\
\text { group }\end{array}$ & $\begin{array}{c}\text { Group } \\
(0.5 \\
\text { \%sepiolite })\end{array}$ & $\begin{array}{c}\text { Group } 2 \\
(1 \% \\
\text { sepiolite })\end{array}$ \\
\hline Corn & 58.30 & 57.30 & 56.20 \\
Soybean meal & 20.60 & 19.20 & 17.60 \\
Sunflower seed meal & 2.00 & 2.00 & 2.00 \\
Full fat soya & 7.00 & 8.90 & 11.10 \\
Limestone & 9.50 & 9.50 & 9.50 \\
Dicalcium phosphate & 1.90 & 1.90 & 1.90 \\
Salt & 0.25 & 0.25 & 0.25 \\
Vitamin-mineral premix & 0.25 & 0.25 & 0.25 \\
DL-methionine & 0.15 & 0.15 & 0.15 \\
Lysine & 0.05 & 0.05 & 0.05 \\
Sepiolite & 0 & 0.50 & 1.00 \\
Chemical composition (Analyzed) & & \\
ME (kcal/kg) & 2750 & 2754 & 2754 \\
Crude protein (\%) & 17.35 & 17.38 & 17.31 \\
Calcium (\%) & 4.11 & 4.10 & 4.12 \\
Total phosphorus (\%) & 0.67 & 0.67 & 0.66 \\
\hline Supplied the following per & &
\end{tabular}

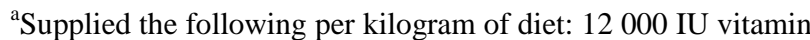
A, $2400 \mathrm{IU}$ vitamin $\mathrm{D}_{3}, 30 \mathrm{mg}$ vitamin $\mathrm{E}, 2.5 \mathrm{mg}$ vitamin $\mathrm{K}_{3}$, $2.5 \mathrm{mg}$ vitamin $\mathrm{B}_{1}, 6 \mathrm{mg}$ vitamin $\mathrm{B}_{2}, 4 \mathrm{mg}$ vitamin $\mathrm{B}_{6}, 20 \mu \mathrm{g}$ vitamin $\mathrm{B}_{12}, 25 \mathrm{mg}$ niacin, $8 \mathrm{mg}$ calcium-D-panthotenate, $1 \mathrm{mg}$ folic acid, $50 \mathrm{mg}$ vitamin $\mathrm{C}, 50 \mu \mathrm{g}$ D-biotin, $150 \mathrm{mg}$ choline chloride, $1.5 \mathrm{mg}$ canthaxanthin, $0.5 \mathrm{mg}$ apo carotenoic acid esther, $80 \mathrm{mg} \mathrm{Mn,} 60 \mathrm{mg} \mathrm{Zn,} 60 \mathrm{mg} \mathrm{Fe}, 5 \mathrm{mg} \mathrm{Cu}, 1 \mathrm{mg} \mathrm{I}, 0.5$ mg Co, $0.15 \mathrm{mg} \mathrm{Se}$.

${ }^{b}$ Metabolizable energy content of diets was estimated according to the equation of Carpenter and Clegg [6].

To determine the egg internal and shell quality characteristics, 100 eggs laid at 0900 to $1200 \mathrm{~h}$ were collected randomly from each group (20 eggs from each replicate in total) during four consecutive days of last week. Each egg was weighed and their shape index was measured with a special instrument (B.V. Apparatenfabreik Van Doorn, No: 75 135/2, De Bilt, Holland). Egg shell breaking strength was measured by using an egg breaking tester (static compression device, Dr.-Ing. Georg Wazau Mess-+Prüftechnick, Berlin, Germany). The egg content was broken onto a glasstopped table. Egg shell thickness was measured in three different parts (upper and lower ends and middle) using a micrometer (Mitutoya, No. 2050-08, 0.01-20 mm; Kawasaki, Japan). The length and width of the albumen and the diameter of the yolk were measured using a digital calliper. By using these values, yolk index [(yolk height / yolk diameter) x 100], albumen index [(albumen height / average of albumen length and albumen width) $x$ 100] and Haugh units $\left[100 \times \log \left(\mathrm{H}+7.57-1.7 \mathrm{~W}^{0.37}\right)\right.$, 
where $\mathrm{H}$ is albumen height and $\mathrm{W}$ is egg weight] were calculated (5). Egg internal and external quality analyses were completed within $24 \mathrm{~h}$ of the eggs being collected. Egg quality evaluation was performed for individual eggs, as it was done in relation to egg weight.

At the end of the experiment, 20 eggs per each group (4 eggs from each replicate) were randomly chosen to determine yolk cholesterol. Eggs were boiled for 5 min. Egg yolk was separated and blended with isopropyl alcohol with a volume of $10 \mathrm{ml}$ per $\mathrm{g}$ of yolk (27). Cholesterol content of this extract was determined according to the enzymatic method of TECO (23). Yolk cholesterol was calculated and expressed as $\mathrm{mg}$ per $\mathrm{g}$ yolk.

Blood samples were collected from vena brachialis under the wing from 15 fed hens randomly chosen from each group (three from each replicate) at the end of the experiment and centrifuged at $3000 \mathrm{x} \mathrm{g}$ for $10 \mathrm{~min}$. Serum was collected and stored at $-20^{\circ} \mathrm{C}$ for determination of total protein, albumin, triglyceride and total cholesterol by Vitros 350 autoanalyser (New York, USA; Product code 680-2153) using their accompanying commercial kits (Vitros Chemistry Products, OrthoClinical Diagnostics, Johnson-Johnson Company, New York, USA).

Statistical analyses: Statistical analyses were done using SPSS programme (SPSS Inc., Chicago, IL, USA). The normality of data distribution was checked using the Kolmogorov-Smirnov test. One-way ANOVA was performed to examine the differences among groups. The significance of mean differences between groups were tested by Tukey. Egg internal and external quality characteristics were analyzed after adjusting egg weight. Values were given as mean \pm standard error of mean. Level of significance was taken as $p<0.05$ (7).

\section{Results}

One hen died in the group fed with diet containing $0.5 \%$ sepiolite during the experimental period. Sepiolite supplementation had no significant effect on body weight, feed intake, hen day egg production, egg weight and feed conversion ratio (Table 2). Dietary treatments did not significantly affect egg shape index, egg albumen height, egg albumen index, egg yolk index and egg Haugh unit (Table 3). However the values of egg breaking strength $(\mathrm{p}<0.01)$ and egg shell thickness $(p<0.05)$ were increased by the usage of $1 \%$ sepiolite in the diet. Dietary sepiolite at $1 \%$ reduced egg yolk cholesterol and serum levels of cholesterol and triglyceride $(\mathrm{p}<0.05)$ as shown in Table 4 . The levels of serum total protein were increased by $1 \%$ sepiolite supplementation $(\mathrm{p}<0.01)$.

\section{Discussion and Conclusion}

Dietary sepiolite supplementation did not significantly affect body weight, feed intake, hen day egg production, egg weight and feed conversion ratio. In

Table 2. The effects of dietary sepiolite on performance of laying hens.

Tablo 2. Rasyona sepiyolit ilavesinin yumurta tavuklarında performans üzerine etkileri.

\begin{tabular}{lcccc}
\hline & Control group & $\begin{array}{c}\text { Group 1 } \\
(0.5 \% \text { sepiolite })\end{array}$ & $\begin{array}{c}\text { Group 2 } \\
\text { (1\% sepiolite) }\end{array}$ & p value \\
\hline Final body weight (g) & $1945 \pm 22$ & $1984 \pm 31$ & $1989 \pm 25$ & 0.458 \\
Feed intake (g/day per hen) & $114.4 \pm 0.7$ & $114.9 \pm 0.5$ & $114.1 \pm 0.4$ & 0.616 \\
Hen-day egg production (\%) & $87.2 \pm 0.7$ & $87.3 \pm 0.7$ & $88.4 \pm 0.4$ & 0.327 \\
Egg weight (g) & $66.2 \pm 0.2$ & $66.3 \pm 0.3$ & $67.0 \pm 0.3$ & 0.199 \\
Feed conversion ratio (g feed per g egg) & $1.98 \pm 0.03$ & $1.99 \pm 0.02$ & $1.93 \pm 0.02$ & 0.223 \\
\hline
\end{tabular}

No significant differences among groups.

Table 3. The effects of dietary sepiolite on egg traits of laying hens ${ }^{1}$.

Tablo 3. Rasyona sepiyolit ilavesinin yumurta tavuklarında yumurta kalitesi üzerine etkileri.

\begin{tabular}{lcccc}
\hline & Control group & $\begin{array}{c}\text { Group 1 } \\
(0.5 \% \text { sepiolite })\end{array}$ & $\begin{array}{c}\text { Group 2 } \\
(1 \% \text { sepiolite })\end{array}$ & p value \\
\hline Egg shape index $(\%)$ & $75.93 \pm 0.25$ & $75.77 \pm 0.29$ & $76.20 \pm 0.27$ & 0.533 \\
Egg breaking strength $\left(\mathrm{kg} / \mathrm{cm}^{2}\right)$ & $2.24 \pm 0.05 \mathrm{~b}$ & $2.47 \pm 0.06 \mathrm{a}$ & $2.56 \pm 0.06 \mathrm{a}$ & $<0.001$ \\
Egg shell thickness $(\mu \mathrm{m})$ & $41.62 \pm 0.37 \mathrm{~b}$ & $42.24 \pm 0.43 \mathrm{ab}$ & $43.02 \pm 0.39 \mathrm{a}$ & 0.035 \\
Egg albumen height $(\%)$ & $7.07 \pm 0.03$ & $7.08 \pm 0.04$ & $7.02 \pm 0.04$ & 0.476 \\
Egg albumen index $(\%)$ & $8.58 \pm 0.07$ & $8.56 \pm 0.08$ & $8.53 \pm 0.07$ & 0.841 \\
Egg yolk index $(\%)$ & $44.00 \pm 0.35$ & $44.85 \pm 0.40$ & $44.30 \pm 0.37$ & 0.276 \\
Egg Haugh unit $(\%)$ & $82.10 \pm 0.23$ & $82.13 \pm 0.27$ & $81.76 \pm 0.25$ & 0.507 \\
\hline
\end{tabular}

1: Values were adjusted to egg weight.

a,b: Means within a row followed by the different superscripts differ significantly $(\mathrm{p}<0.05)$. 
Table 4. The effects of dietary sepiolite on egg yolk cholesterol and some blood serum parameters in laying hens.

Tablo 4. Rasyona sepiyolit ilavesinin yumurta tavuklarında yumurta sarısı kolesterolü ve bazı kan parametreleri üzerine etkileri.

\begin{tabular}{lcccc}
\hline & Control group & $\begin{array}{c}\text { Group 1 } \\
(0.5 \% \text { sepiolite })\end{array}$ & $\begin{array}{c}\text { Group 2 } \\
(1 \% \text { sepiolite })\end{array}$ & $\mathrm{p}$ value \\
\hline Egg yolk cholesterol $(\mathrm{mg} / \mathrm{g}$ yolk) & $15.72 \pm 0.17 \mathrm{a}$ & $15.63 \pm 0.15 \mathrm{a}$ & $15.03 \pm 0.19 \mathrm{~b}$ & 0.011 \\
Serum total protein $(\mathrm{g} / \mathrm{l})$ & $51.71 \pm 0.72 \mathrm{~b}$ & $52.37 \pm 1.00 \mathrm{~b}$ & $56.35 \pm 0.97 \mathrm{a}$ & 0.001 \\
Serum albumin $(\mathrm{g} / \mathrm{l})$ & $22.23 \pm 0.36$ & $22.20 \pm 0.43$ & $22.37 \pm 0.30$ & 0.942 \\
Serum cholesterol $(\mathrm{g} / \mathrm{l})$ & $1.43 \pm 0.05 \mathrm{a}$ & $1.42 \pm 0.04 \mathrm{ab}$ & $1.28 \pm 0.04 \mathrm{~b}$ & 0.026 \\
Serum triglyceride $(\mathrm{g} / \mathrm{l})$ & $14.11 \pm 0.20 \mathrm{a}$ & $13.92 \pm 0.23 \mathrm{ab}$ & $13.26 \pm 0.22 \mathrm{~b}$ & 0.022 \\
\hline
\end{tabular}

a,b: Means within a row followed by the different superscripts differ significantly $(\mathrm{p}<0.05)$.

agreement with the present study Mizrak et al. (14) reported that dietary sepiolite at the levels of $1 \%$ and $2 \%$ didn't affect the body weight, feed intake, hen day egg production, egg weight and feed efficiency in laying breeder hens. Tortuero et al. (25) also observed that sepiolite supplementation did not influence feed intake, egg production, egg weight and feed conversion ratio. Ouhida et al. (20) showed that dietary sepiolite at $1 \%$ and $2 \%$ had no significant effect on body weight, feed intake and feed efficiency in broilers. Palygorskite (a clay with similar physical properties to sepiolite) supplementation at $1 \%$ in diets had no significant effect on feed efficiency in broilers (21). However Eser et al. (10) reported that body weight was enhanced by sepiolite addition into broiler diets but feed intake and feed efficiency values were not changed among groups.

The improvement in growth performance with the usage of sepiolite might be explained that sepiolite usage may increase the digesta retention time and therefore the endogenous enzyme activity might be more effective in the digestion of fat, protein and carbohydrates and improve their absorption $(19,20,24)$. However in the present study no positive effect was observed on laying performance. This might be due to the species of animals, sepiolite dose, diet ingredients and diet composition.

One hen died in the group fed with diet containing $0.5 \%$ sepiolite during the experimental period and mortality was not treatment related. Similarly some researchers observed that sepiolite usage in broilers (3, $10)$ and in layers $(14,15)$ had no effect on mortality rate.

Dietary treatments did not significantly affect egg shape index, egg albumen height, egg albumen index, egg yolk index and egg Haugh unit. However the values of egg breaking strength $(\mathrm{p}<0.01)$ and egg shell thickness $(p<0.05)$ were increased by the usage of $1 \%$ sepiolite in the diet. Improvement in egg shell quality might be explained that sepiolite may increase calcium utilization. However Mizrak et al. $(14,15)$ reported that egg shape index, breaking strength, shell thickness and haugh unit were not affected by the usage of sepiolite. Tortuero et al. (25) concluded that egg shell quality and relative weight percentages of egg shell, yolk and albumen were not affected by dietary sepiolite.

A significant reductions $(\mathrm{p}<0.05)$ in egg yolk cholesterol content as mg per g yolk were observed in the group fed diet containing $1 \%$ sepiolite. Dietary sepiolite at $1 \%$ also reduced serum levels of cholesterol and triglyceride $(\mathrm{p}<0.05)$. Similarly Eser et al. (10) reported that serum cholesterol and triglyceride were reduced by dietary sepiolite in broilers. This reduction in yolk cholesterol might be explained by the reduced absorption, synthesis or both of cholesterol in the gastrointestinal tract (17). Sepiolite supplementation at the level of $1 \%$ increased serum total protein $(\mathrm{p}<0.01)$ however didn't affect blood serum albumin. Safaei Katouli et al. (22) reported that serum triglyceride was decreased and serum total protein was increased in group fed diets containing 1.5\% kaolin in compared to control group. The increase in serum protein could be due to the action of kaolin on the enhanced digestibility of protein (22). However Eser et al. (10) reported that serum total protein was not affected by the usage of sepiolite in broiler diets. Some researchers determined that hydrated sodium calcium aluminosilicates did not result in any significant changes in serum chemistry in trials with chicks $(4,8,13,15)$.

The results of this study indicate that $1 \%$ sepiolite in the diets improve egg shell quality and reduce egg yolk cholesterol, blood serum cholesterol and triglyceride. No adverse effects were seen on the other parameters. Therefore it was concluded that dietary supplementation of $1 \%$ sepiolite was effective in layer feeding.

\section{References}

1. ADAS (1981): The Analysis of Agricultural Materials. Ministry of Agriculture, Fisheries and Food, Agricultural Development and Advisory Service, 2nd ed., Her Majesty's Stationery Office, London, UK.

2. AOAC (2000): Official Methods of Analysis. 17th ed. Association of Official Analytical Chemists, AOAC International, Maryland, USA.

3. Ayed MH, Zghal I, Rekik B (2008): Effect of sepiolite supplementation on broiler growth performances and 
carcass yield. Proceedings, Western Section, American Soc Anim Sci, 59: 169-172.

4. Bailey CA, Latimer GW, Barr AC, Wigle WL, Haq AU, Balthrop JE, Kubena LF (2006): Efficacy of montmorillonite clay (NovaSil PLUS) for protecting fullterm broilers from aflatoxicosis. J Appl Poult Res, 15, 198206.

5. Card LE, Nesheim MC (1972): Poultry Production. 11th ed. Lea and Febiger, Philadelphia, USA.

6. Carpenter KJ, Clegg KM (1956): The metabolizable energy of poultry feedingstuffs in relation to their chemical composition. J Sci Food Agric, 7, 45-51.

7. Dawson B, Trapp RG (2001): Basic and Clinical Biostatistics, 3rd ed., Lange Medical Books/McGraw-Hill Medical Publishing Division, New York, USA.

8. Dwyer MR, Kubena LR, Harvey RB, Mayura K, Sarr AB, Buckley S, Bailey RH, Phillips TD (1997): Inorganic absorbents and cyclopiazonic acid in broiler chickens. Poultry Sci, 76, 1141-1149.

9. EFSA (2013): Scientific opinion on the safety and efficacy of a preparation of bentonite-sepiolite $\left(\right.$ Toxfin $^{R}$ Dry) as feed additive for all species. European Food Safety Authority, EFSA J, 11, 3179. p.1-21.

10. Eser H, Yalçın S, Yalçın S, Şehu A (2012): Effects of sepiolite usage in broiler diets on performance, carcass traits and some blood parameters. Kafkas Üniv Vet Fak Derg, 18, 313-318.

11. Farese G, Schmidt JL, Mager M (1967): An automated method for the determination of serum calcium with glyoxal bis (2-hydroxyanil). Clin Chem, 13, 515-520.

12. Galan E (1996): Properties and applications of palygorskite-sepiolite clays. Clay Miner, 31, 443-453.

13. Kubena LF, Harvey RB, Huff WE, Elissalde MH, Yersin AG, Phillips TD, Rottinghaus GE (1993): Efficacy of a hydrated sodium calcium aluminosilicate to reduce the toxicity of aflatoxin and diacetoxyscirpenol. Poultry Sci, 72, 51-59.

14. Mrzrak C, Yenice E, Ertekin B (2013): Effects of sepiolite to feeds of laying breeder hens containing low calcium levels on performance, egg quality, some blood and digestive system. Lalahan Hay Araşt Enst Derg, 53, 75-89 (Turkish with English summary).

15. Mızrak C, Yenice E, Kahraman Z, Tunca M, Yıldırım U, Ceylan N (2014): Effects of dietary sepiolite and mannanoligosaccharide supplementation on the performance, egg quality, blood and digestion characteristics of laying hens receiving aflatoxin in their feed. Ankara Üniv Vet Fak Derg,61, 65-71.

16. Miles RD, Henry PR (2007): Safety of improved MilbondTX when fed in broiler diets at greater than recommended levels. Anim Feed Sci Technol, 138, 309-317.

17. Mohan B, Kadirvel M, Bhaskaran M, Natarajan A (1995): Effect of probiotic supplementation on serum yolk cholesterol and on egg shell thickness in layers. Br Poult Sci, 36: 799-803.
18. Murray HH, Pozo M, Galan E (2011): An introduction to palygorskite and sepiolite deposits-location, geology and uses. In: Galan E., Singer A. (Eds): Developments in Palygorskite-Sepiolite Research: A New Outlook on These Nanomaterials, $1^{\text {st }}$ ed., pp. 85-91, Elsevier B.V., Amsterdam, The Netherlands.

19. Ouhida I, Perez JF, Gasa J, Puchal, F (2000). Enzymes ( $\beta$-glucanase and arabinoxylanase) and/or sepiolite supplementation and the nutritive value of maize-barleywheat based diets for broiler chickens. Br Poult Sci, 41: 617-624.

20. Ouhida I, Perez JF, Piedrafita J, Gasa J (2000): The effect of sepiolite in broiler chicken diets of high, medium and low viscosity. Productive performance and nutritive value. Anim Feed Sci Technol, 85, 183-194.

21. Pappas AC, Zoidis E, Theophilou N, Zervas G, Fegeros K (2010): Effects of palygorskite on broiler performance, feed technological characteristics and litter quality. Appl Clay Sci, 49, 276-280.

22. Safaei Katouli M, Jafarlahangari Y, Baharlouei A (2011): An evaluation on the effects of dietary kaolin and zeolite on broilers blood parameters, T4, TSH and growth hormones. Pakistan J Nutr, 10, 233-237.

23. TECO (2001): Cholesterol (Liquid) reagent. C507. Teco Diagnostics. Anaheim, USA.

24. Tortuero Cosialls F, Fernandez Gonzalez E, Martin Martin L (1992): Effects of dietary sepiolite on the growth, visceral measurements and food passage in chickens. Arch Zootec, 41, 209-217.

25. Tortuero F, Rioperez J, Martin L (1993). Effect of dietary sepiolite supplementation on the performance, egg composition and mineral metabolism in laying hens. Arch Zootec, 42, 347-360.

26. Viseras C, Lopez-Galindo A (1999): Pharmaceutical application of some Spanish clays (sepiolite, palygorskite, bentonite): some preformulation studies. Appl Clay Sci, 14, 69-82.

27. Waldroup PW, Ndide LI, Hellwig HM, Hebert JA, Berrio L (1986): Influence of probucol (4,4'isopropylidine dithio)-bis(2,6-di-t-butyl-phenol) on egg yolk cholesterol content and performance of laying hens. Poultry Sci, 65, 1949-1954.

Geliş tarihi: 02.07.2014 / Kabul tarihi: 25.02.2015
Address for correspondence:
Prof. Dr. Sakine Yalçın
Ankara Üniversitesi, Veteriner Fakültesi
Hayvan Besleme ve Beslenme Hastalıklarl Anabilim Dalı
Dışkapı-Ankara
e-mail: sayalcin@ankara.edu.tr 